ISOCRATES II 
THE ORATORY OF CLASSICAL GREECE

Translated with Notes - Michael Gagarin, Series Editor VOLUME 7 


\section{ISOCRATES II}

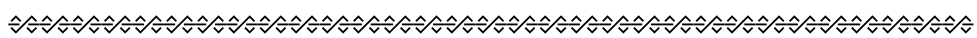

Translated by Terry L. Papillon

$\checkmark$ UNIVERSITY OF TEXAS PRESS, AUSTIN 
Copyright (O) 2004 by the University of Texas Press All rights reserved

Printed in the United States of America

First edition, 2004

Requests for permission to reproduce material from this work should be sent to Permissions, University of Texas Press, Box 7819, Austin, TX 78713-7819.

(2) The paper used in this book meets the minimum requirements of ANSI/NISO Z39.48-1992 (RI997) (Permanence of Paper).

Library of Congress Cataloging-in-Publication Data

Isocrates.

[Selections. English. 2004]

Isocrates II / translated by Terry L. Papillon.

p. $\quad \mathrm{cm} .-$ (The oratory of Classical

Greece ; v. 7)

Includes bibliographical references and index.

ISBN 0-292-70245-O (hardcover : alk. paper) ISBN 0-292-70246-9 (pbk. : alk. paper)

I. Isocrates-Translations into English.

2. Speeches, addresses, etc., Greek-Translations into English. 3. Athens (Greece)-Politics and government-Sources. I. Title: Isocrates 2. II. Title: Isocrates two. III. Papillon, Terry L., 1958 - IV. Title. V. Series.

PA42I7.E5P37 2004

$885^{\prime}$.OI-dc22 